Research Article

\title{
The Incidence of Anal Sphincter Ruptures and Risk Factors
}

\author{
Kejadian Ruptur Sfingter Ani dan Faktor-faktor Risikonya
}

\author{
Budi I Santoso, Denny Khusen \\ Department of Obstetrics and Gynecology \\ Faculty of Medicine University of Indonesia/ \\ Dr. Cipto Mangunkusumo Hospital
}

Jakarta

\begin{abstract}
Objective: To analyze the incidence of anal sphincter ruptures and to evaluate risk factors of obstetric anal sphincter ruptures in Dr. Cipto Mangunkusumo Hospital.

Method: We reviewed 2009 vaginal deliveries based on the analysis of obstetric data base and patient records of our department during 2012. Cases and control subjects were chosen randomly and patient's records were reviewed for the following variable: maternal age, parity, gestational age, labor induction, duration of $2^{\text {nd }}$ stage labor, use of forceps, use of vacuum, use of episiotomy, birth weight, and presentation of the baby.

Result: There were 91 (4.53\%) anal sphincter ruptures during period of study ( 91 of 2009 patients). An univariate analysis of these 91 case and 91 randomly selected control subjects show that primiparity $(p=.000)$, gestational age $(p=.016)$, duration of second-stage labor $(p=.000)$, forceps delivery $(p=.000)$, vacuum delivery $(p=$ $.001)$, episiotomy $(p=.000)$, and birth weight $(p=.000)$ increased the risk for anal sphincter ruptures. In multivariate re-gression models, only 5 of the 10 predictor variables were significantly related to the likelihood of having a severe perineal trauma greater than second degree. Primiparity ( $p=.023$; OR 2.74, 95\% [CI], 1.15-6.51), forceps delivery ( $p=.000$; OR 18.18, 95\% [CI] 3.84-86.07), vacuum delivery ( $p=.005$; OR 6.83, 95\% [CI] 1.77-26.42), episiotomy ( $p=$ .015 ; OR 2.86, 95\% [CI] 1.23-6.65), and birth weight ( $p=.000$; OR $0.99,95 \%$ [CI] 0.997-0.999).
\end{abstract}

Conclusion: Damage of the anal sphincter resulting in a third- or fourth- degree perineal tear is a relatively rare but severe complication of vaginal delivery. We found that factors as sociated with anal sphincter ruptures were primiparity, forceps, vacuum, episiotomy and birth weight.

[Indones J Obstet Gynecol 2016; 1: 31-36]

Keywords: anal sphincter ruptures, third- or fourth- degree perineal tear, vaginal delivery

\begin{abstract}
Abstrak
Tujuan: Untuk menganalisis kejadian ruptur sfingter ani dan mengevaluasi faktor risiko obstetrik ruptursfingter ani di Rumah Sakit Dr. Cipto Mangunkusumo.
\end{abstract}

Metode: Kami meneliti secara retrospektif 2009 kelahiran pervaginam berdasarkan analisis data base obstetrik dan catatan pasien di departemen kami selama tahun 2012. Kasus dan kontrol yang dipilih secara acak dan catatan pasien ditinjau untuk melihat variabelvariabel berikut usia ibu, paritas, usia kehamilan, induksi persalinan, lama persalinan stage 2, penggunaan forseps, penggunaan vakum, penggunaan episiotomi, berat lahir dan presentasi bayi.

Hasil: Ada 91 (4,53\%) kejadian ruptur sfingter ani selama periode penelitian (91 dari 2009 pasien). Sebuah analisis univariat dari 91 kasus dan 91 kontrol yang dipilih secara acak menunjukkan bahwa primipara $(p=0,000)$, usia kehamilan $(p=0,016)$, lama persalinan stage kedua ( $p=$ $0,000)$, forseps $(p=, 000)$, vakum $(p=, 001)$, episiotomi $(p=0,000$, dan berat bayi lahir $(p=0,000)$ meningkatkan risiko ruptur sfingter ani. Dalam model regresi multivariat, hanya 5 dari 10 variabel prediktor secara signifikan terkait dengan kemungkinan memiliki ruptur perineum yang berat lebih besar dari derajat kedua. Primipara ( $p=0,023 ;$ OR 2,74, 95\% [CI] 1,15-6,51), forseps ( $p=0,000$, OR 18,18, 95\% [CI] 3,84-86,07), vakum ( $p=0,005 ;$ OR 6,83,95\% [CI] 1,77-26,42), episiotomi ( $p=0,015$, OR 2,86, 95\% [CI] 1,23-6,65), dan berat bayi lahir ( $p=0,000$; OR 0,99, 95\% [CI] 0,997-0,999].

Kesimpulan: Kerusakan sfingter ani mengakibatkan robekan perineum derajat ketiga atau keempat adalah komplikasi yang relatif jarang namun bila terjadi mempunyai komplikasi yang berat dalam persalinan pervaginam. Dalam studi ini, kami menemukan bahwa faktor yang terkait dengan ruptur sfingter ani adalah primipara, forseps, vakum, episiotomi, dan berat bayi lahir.

[Maj Obstet Ginekol Indones 2016; 1: 31-36]

Kata kunci: persalinan pervaginam, robekan perineum derajat ketiga atau keempat, ruptur sfingter ani

Correspondence. Denny Khusen. Jln. Pluit Karang Manis Blok D7 Barat no. 72, Jakarta. Tel: +62-852-8661-4785, E-mail: dennyddk09@yahoo.com

\section{INTRODUCTION}

Obstetric anal sphincter ruptures may be seen at the time of birth ('overt') or may be detected only after additional ultrasound investigation, after birth ('occult'). As many as $85 \%$ of women who give birth vaginally will experience trauma to the perineum and $3-12 \%$ will be the anal sphincter muscle. Tear in the anal sphincter muscles will cause disruption to the muscles of the pelvic floor in the future. Damage of the anal sphincter resulting in a third- or fourth- degree perineal tear is a relatively rare but severe complication of vaginal delivery. The incidence of 'overt' anal sphincter injury has previously been reported in about 2.5\% of vaginal deliveries with mediolateral episiotomy and about $11 \%$ with midline episiotomy. ${ }^{1}$ However, $33 \%$ of women sustain occult anal sphincter 
rupture during vaginal delivery. ${ }^{2}$ The most plausible explanation for an occult rupture is either that an injury that has been missed or it has been wrongly classified as a second-degree tear. Forceps delivery, midline episiotomy, first vaginal delivery, larger baby, shoulder dystocia and a persistent occipito-posterior position have been identified as the main risk factors for the development of a third- fourth- degree tear. ${ }^{3}$

It might seem logical to assume that an increased grade of tear should be associated with increased severity of anal incontinence. However, while some studies have shown an association between symptoms of anal incontinence and increased degree of rupture ${ }^{4,5}$, others have found there is no relationship. ${ }^{6}$

Anal incontinence after childbirth may be due to injury to the anal sphincter or its innervation, or both. ${ }^{7}$ A rupture involving the anal sphincter during vaginal delivery has great bearing on a woman's future continence. Primary sphincter repair, performed by obstetricians immediately after delivery, has traditionally been regarded as providing a good outcome. However, recent studies in a total of 70 patients have reported subsequent anal incontinence in $29-48 \%$ of women three months to three years after primary sphincter repair.

In addition, patients sustaining third- or fourthdegree perineal tears are at a higher risk for the development of infection and rectovaginal fistulae. ${ }^{8,9}$ As a result, the number of women requesting caesarean section is constantly growing in western European countries, thereby causing controversy between obstetricians on how to reduce maternal intrapartum and postpartum complications to provide optimal care of child bearing patient. It has therefore been the subject of several studies to identify potential risk factors associated with the development of perineal lacerations during vaginal delivery. Identified maternal and delivery variables reported in previous works include parity, maternal age, race, use of episiotomy, birth weight, assisted vaginal delivery, and induction of labor.8-10

The aims of the present work were to identify the incidence of anal sphincter rupture and to evaluate risk factors of obstetric anal sphincter tears. All women who had experienced second and third degree tear over a 12 month period in one obstetric unit of a teaching hospital were included in this study.

\section{METHODS}

This was an observational retrospective case-control based on register study. These analysis of obstetric variables using a 1:1 ratio of cases and control subjects. The information was taken from the Hospital Discharge Register equated to ICD-10 codes 070.2 (third- degree) and 070.3 (fourth- degree). The two data sources were linked together using the mothers' unique personal identification numbers. The degree was classified according to standard definitions: a third- degree rupture involves the external anal sphincter and a fourth- degree rupture affects both the anal sphincter and anorectal mucosa. ${ }^{11}$ The degree of perineal trauma was assessed by obstetricians.

Women included in this study delivered their children (between January 2012 and December 2012) at the Department of Obstetrics and Gynecology Dr. Cipto Mangunkusumo Hospital, all deliveries were studied and analyzed with respect to risk factors for development of anal sphincter ruptures.

During the study period of 12 months, there were 2009 women undergoing vaginal delivery. Patients with multiple pregnancies $(\mathrm{n}=71)$, induction of labor $(n=70)$, breech deliveries $(n=7)$, episiotomy ( $n=94)$, forceps deliveries $(n=24)$, vacuum deliveries $(n=25)$. After strict application of in and exclusion criteria, data were divided into 2 groups: 1 group (cases) including all patients (n $=109$ ) with laceration of the perineum greater than second degree. Perineal tears were classified into four degrees according to the international classification of diseases. ${ }^{12}$ A first- degree tear involved the forche, the perineal skin, vaginal epithelium but not the underlying fascia and muscles. A second- degree tear also involved the fascia, muscles, perineal body but not the anal sphincter. A third- degree tear involved the anal sphincter, but does not extend through the rectal mucosa. A fourth- degree tear was defined as extending through the rectal mucosa. The second group (controls) was selected randomly on the basis of a blinded protocol from women undergoing vaginal delivery without anal sphincter ruptures.

All delivery records were studied and the following parameters were registered: age, parity, gestational age, induction of labor, duration of second stage labor, episiotomy, forceps delivery, vacuum delivery, presentation of the fetus, and birth weight. 
Researches data obtained were recorded in a special form provided, then were tabulated and analyzed with the help of SPSS (Statistic Package for Social Science) computer software v.16 for Windows. Distribution of maternal and obstetrical predictor variables was compared with the use of TTest and Chi Square Test. P value less than 05 was considered statistically significant. Multivariate logistic regression analysis was performed to evaluate to influence of potentially influencing the occurrence of third- or fourth- degree perineal tears considered in the logistic regression model.

\section{RESULTS}

In 2009 vaginal deliveries that were reviewed during study period, the incidence of anal sphincter ruptures was 4.53\% (91 of 2009 patients). Mean maternal age in the sample group was 26.81 years and 27.71 years in controls (not significant, $p>05$ ). Results of univariate analysis of maternal characteristics and delivery details of cases and control are listed in Tables 1 and 2. As shown, there were no significant differences in the age, induction, and presentation of the baby. Women with greater than third- degree tearing were more likely to be primiparity than the controls $(p=.000)$. Furthermore, gestational age $(p=.016)$, duration of second-stage labor $(p=.000)$, forceps delivery $(p=.000)$, vacuum delivery ( $p=.001)$, episiotomy $(p=.000)$, birth weight $(p=.000)$ were significantly associated with the occurrence of third- and fourth- degree perineal tears between the 2 groups (Table 2 ). Table 3 shows the results of a multivariate logistic regression model. Only 5 of the 10 predictor variables were significantly related to the likelihood of having a severe perineal trauma greater than second degree. Primiparity ( $\mathrm{p}=.023$; OR 2.74, 95\% confidence interval [CI], 1.15-6.51), forceps delivery $(\mathrm{p}=.000$; OR $18.18,95 \%$ confidence interval [CI] 3.84-86.07), vacuum delivery ( $\mathrm{p}=.005$; OR 6.83, 95\% confidence interval [CI] 1.77-26.42), episiotomy ( $\mathrm{p}=.015$; OR $2.86,95 \%$ confidence interval [CI] 1.23-6.65), and birth weight ( $\mathrm{p}=.000$; OR 0.99, 95\% confidence interval [CI] 0.997-0.999) were all significantly more common in women who sustained a third- degree tear than in those women who did not.

Table 1. Maternal Characteristics of the Study Population and Univariate Analysis of Cases and Controls by T-Test and Chi Square Test.

\begin{tabular}{lccc}
\hline \hline Characteristic & Cases & Controls & Statistical significance (p $\leq .05)$ \\
\hline Mean age & 26.81 & 27.71 & 0.320 \\
Primiparity (yes/no) & $21(83.3 \%)$ & $3(16.7 \%)$ & $0.000^{*}$ \\
Mean gestational age & 38.33 & 37.33 & $0.016^{*}$ \\
$<35 \mathrm{wk}$ & $5(31.3 \%)$ & $11(68.8 \%)$ & \\
$35-36 \mathrm{wk}$ & $10(40 \%)$ & $15(60 \%)$ & \\
$37-38 \mathrm{wk}$ & $17(37.8 \%)$ & $28(62.2 \%)$ & \\
$39-40 \mathrm{wk}$ & $43(59.7 \%)$ & $29(40.3 \%)$ & \\
Postdates $>40 \mathrm{wk}$ & $16(66.7 \%)$ & $8(33.3 \%)$ & \\
\hline \hline
\end{tabular}

Table 2. Delivery Details of the Study Population and Univariate Analysis of Cases and Controls by T-Test and Chi Square Test.

\begin{tabular}{lccc}
\hline \hline Characteristic & Cases & Controls & Statistical significance (p $\leq .05)$ \\
\hline Labor induction (yes/no) & $36(51.4 \%)$ & $34(48.6 \%)$ & 0.879 \\
Mean duration of 2nd stage (min) & 23.54 & 14.29 & $0.000^{*}$ \\
Forceps (yes/no) & $21(87.5 \%)$ & $3(12.5 \%)$ & $0.000^{*}$ \\
Vacuum (yes/ no) & $21(84 \%)$ & $4(16 \%)$ & $0.001^{*}$ \\
Episiotomy (yes/ no) & $69(73.4 \%)$ & $25(26.6 \%)$ & $0.000^{*}$ \\
Mean birth weight (g) & 3329.89 & 2769.34 & $0.000^{*}$ \\
Below 3000 g & $25(32.5 \%)$ & $52(67.5 \%)$ & 1.000 \\
3000 g to 4000 g & $62(61.4 \%)$ & $39(38.6 \%)$ & $0(0 \%)$ \\
Above 4000 g & $4(100 \%)$ & $3(42.9 \%)$ & \\
Presentation (buttock/head) & $4(57.1 \%)$ & & \\
\hline \hline
\end{tabular}


Table 3. Outcome of Multivariate Logistic Regression Analysis on Variables that Potentially Influence the Incidence of $3^{\text {rd }} / 4^{\text {th }}$ Degree Lacerations.

\begin{tabular}{lcc}
\hline \hline Characteristic & Odds Ratio (95\% CI) & Statistical significance $(\mathbf{p} \leq \mathbf{. 0 5})$ \\
\hline Primiparity (yes/no) & $2.74(1.15-6.51)$ & $0.023^{*}$ \\
Gestational Age & $1.203(0.968-1.496)$ & 0.096 \\
Duration of 2nd stage & $0.989(0.949-1.031)$ & 0.604 \\
Forceps (yes/no) & $18.181(3.841-86.068)$ & $0.000^{*}$ \\
Vacuum (yes/no) & $6.834(1.768-26.415)$ & $0.005^{*}$ \\
Episiotomy(yes/no) & $2.862(1.231-6.651)$ & $0.015^{*}$ \\
Birth Weight & $0.998(0.997-0.999)$ & $0.000^{*}$ \\
\hline${ }^{*}=$ meaningful & &
\end{tabular}

\section{DISCUSSION}

Anal sphincter ruptures are an uncommon complication of childbirth, although these tears are uncommon, we have shown that primary sphincter repair in these women is often unsatisfactory and associated with morbidity. The present study depicts risk factors that are associated with anal sphincter ruptures during spontaneous vaginal deliveries at Dr. Cipto Mangunkusumo Hospital. The goal of the present work was to identify for third and fourth degree perineal lacerations. Ninety one $(4.53 \%)$ out of 2009 patients experienced $\geq$ thirddegree perineal tears during vaginal delivery. Using cases and control subject univariate analysis revealed age, primiparity, gestational age, induction of labor, duration of second stage labor, forceps delivery, vacuum delivery, episiotomy, birth weight, and presentation of the baby as risk factors for disruption of the anal sphincter. The effect of unalterable maternal factors such as age, weight on the frequency of severe ruptures has been investigated, but the results are varying in different studies. ${ }^{13,14}$

Age differences between cases and controls statistically and clinically 1 years were found not meaningful. This is probably caused by the number of patients with relatively a few cases, so it did not give significant differences.

Primiparity is one of the most important risk factors, since primiparous have up to a 10 -fold increased risk of anal sphincter ruptures. In keeping with other studies, we found that primiparous women were at greater risk of sustaining a third degree tear than women who had already had a vaginal delivery. This probably relates to relative in elasticity of the perineum. Differences in the elasticity and strength of connective tissue between nulliparous and parous women could be one explanation. There are few studies on those differences. A previous report by Petersen and Uldbjerg demonstrated that the content of hydroxyproline and the strength of the collagen in the uterine cervix of multiparas is reduced. If other risk factors are also present the attending obstetrician should anticipate the possibility of a major tear. ${ }^{15-}$ ${ }^{17}$ From our research, it was found that primiparity play an important role in the risk of anal sphincter ruptures.

Gestational age was associated with an increased risk for sphincter tears, which has been reported by Crawford et al. However, neither Sorensen et al nor Combs et al found such an association. We have no definite explanation for our finding. Gestational age was found to be an independent risk factor and an increased fetal weight is thus not the only explanation. Hormonal changes during pregnancy might alter connective tissue properties. The long standing effect of gravitational forces on the pelvic floor could also associate with changes in connective tissue. ${ }^{18-20}$ Interestingly, gestational age was associated with a higher rate of sphincter damage in univariate analysis but did not prove to be an independent risk factor in the multivariate regression model.

Labor induction differences between cases and controls statistically and clinically 1 years were found not meaningful. This is probably caused by the number of patients with relatively a few cases, so it did not gives ignificant differences.

Duration of second stage was associated with a higher rate of sphincter damage in univariate analysis but did not prove to be an independent risk factor in the multivariate regression model. 
Vaginal operative delivery, especially the use of forceps or vacuum, is a well-known cause of thirdand fourth- degree perineal tears. The majority of research conducted in this field showed that forceps delivery significantly predicted anal sphincter injury. ${ }^{8-10,21}$ However, in a retrospective study of 16,172 primigravid vaginal deliveries conducted by Gupta et al, instrumental delivery by the aid of forceps was not found to be an independent risk factor for sphincter damage with $36(1.6 \%)$ of 2311 forceps deliveries resulting in third- degree lacerations. In contrast to several studies showing that anal sphincter injury is likely to complicate more than $60 \%$ of forceps deliveries, the incidence of $1.6 \%$ presented by Gupta and colleagues and another $13 \%$ in a prospective study investigating 93 females undergoing forceps delivery by de Parades et al is surprisingly low. ${ }^{22,23}$ The present study clearly identified forceps and vacuum delivery as an independent risk factor for anal sphincter ruptures using cases and control. Instrumental delivery is known to increase risk for sphincter ruptures, and this risk is more pronounced with forceps compared with vacuum delivery. However, any intervention that substantially accelerates the last part of the second stage of labor could be harmful to the tissues of the pelvic floor.

Whether episiotomy is beneficial in the prevention of obstetric and anal sphincter ruptures (OASR) is an open question and under constant debate. Nowadays, limiting the use of episiotomy is recommended, since this appears to have a number of benefits such as less suturing and fewer complications. ${ }^{24}$ We have previously reported that episiotomy is associated with a lower OASR rate in first births and a higher rate in second and subsequent births. ${ }^{25}$ The role of episiotomy as a contributing factor for third- and fourth- degree lacerations is discussed controversially. By investigating a total of 50,210 vaginal deliveries, Angioli et al concluded that the episiotomy procedure per se, regardless of the type of episiotomy used, represents an independent risk factor for sphincter disruption. ${ }^{26}$ Bek et al, Bodner et al, and BodnerAdler and colleagues found an increased risk of anal sphincter tear when episiotomy was used. ${ }^{21-28}$ By contrast, Poen et al, Shiono et al, and de Leeuw et al showed that episiotomy was protective against anal sphincter damage and fecal incontinence after vaginal delivery, and Hendriksen and coworkers and Buekens et al found no association between episiotomy and lesions of the anal sphinc- ter. $^{2,22,29}$ In the present study, the use of episiotomy conferred an increased risk of severe perineal damage.

Many studies compare macrosomic infants to infants with lower birth weight and find a significant association between high birth weight and risk of anal sphincter ruptures. ${ }^{15,16}$ Higher birth weight is associated with bigger head circumference, and some authors have reported a larger head to be a risk factor for sphincter damage. ${ }^{30}$ In accordance with previous data, high birth weight was an independent risk factor for the occurrence of third- and fourth- degree perineal lacerations. ${ }^{13}$ One simple reason may be the greater susceptibility and vulnerability to disruption of a perineum that is exposed to a greater tension with higher birth weight. From our statistical research conducted by us, it was found that a high birth weight had a role in the incidence of anal sphincter ruptures.

Presentation of the baby did not show significant thing in this study. This is probably caused by the number of patients with relatively a few cases, so it did not give significant differences.

\section{CONCLUSION}

In this study, we found that factors associated with anal sphincter ruptures were primiparity, forceps, vacuum, episiotomy, and birth weight. The most significant risk factors found for anal sphincter ruptures was forceps. Anal sphincter ruptures are an uncommon but serious complication of vaginal delivery. When multiple risk factors are present, special attention should be directed to preventing ruptures. Primary sphincter repair seems to be in adequate in at least half the women, often resulting in persistent symptoms. Because incontinence can be such a devastating social disability, the nature of sphincter repair deserves serious further attention. The goal of this study is to find out the causes of anal sphincter ruptures, so this incidence can be anticipated and be reduced.

\section{REFERENCES}

1. Sultan AH. Anal incontinence after childbirth. Curr Opin Obstet Gynecol, 1997; 9: 320-4.

2. De Leeuw JW, Vierhout ME, Struijk PC et al. Anal sphincter damage after vaginal delivery: functional outcome and risk factors for incontinence. Acta Obstet Gynecol Scand, 2001; 80: 830-4.

3. RCOG: London. The Management of third- and fourth- degree perineal tears. Royal College Obstet Gynecol Green-top Guideline, 2007: 29. 
4. Nichols CM, Lamb EH, Ramakrishnan V. Differences in outcomes after third- versus fourth- degree perineal laceration repair: A prospective study. Am J Obstet Gynecol, 2005; 193: 530-6.

5. Norderval S, Oian P, Revhaug A et al. Anal incontinence after obstetric sphincter tears: outcome of anatomic primary repairs. Dis Colon Rectum, 2005; 48: 1055-61.

6. Starck M, Bohe M, Valentin L. The extent of endosonographic anal sphincter defects after primary repair of obstetric sphincter tears increases over time and is related to anal incontinence. Ultrasound Obstet Gynecol 2006; 27: 188-97.

7. Sultan AH, Thakar R. Third and fourth degree tears. In Perineal and Anal Sphincter Trauma, Sultan AH, Thakar R, Fenner DE (eds). Springer-Verlag: London, 2007: 33-51.

8. Richter HE, Brumfield CG, Cliver SP et al. Risk factors associated with anal sphincter tear: a comparison of primiparous patients, vaginal births after cesarean deliveries, and patients with previous vaginal delivery. Am J Obstet Gynecol, 2002; 187: 1194-8.

9. Christianson LM, Bovbjerg VE, Mc Davitt EC et al. Risk factors for perineal injury during delivery. Am J Obstet Gynecol, 2003; 189: 255-60.

10. Golgberg J, Hyslop T, Tolosa JE et al. Racial differences in severe perineal lacerations after vaginal delivery. Am J Obstet Gynecol, 2003; 188: 1063-7.

11. Power D, Fitzpatrick M, O’Herlihy C. Obstetric anal sphincter injury: how to avoid, how to repair. A literature review. J Fam Pract, 2006; 55(3): 193-200.

12. World Health Organization. International classification of diseases, $9^{\text {th }}$ revision, clinical modification (ICD-9-CM). Geneva, Switzerland, 1996.

13. Hudelist G, Gelle'n J, Singer C et al. Factor predicting severe perineal trauma during childbirth: Role of forceps delivery routinely combined with mediolateral episiotomy. Obstet Gynecol, 2005; 192: 875-81.

14. Aukee P, Sundstrom H, Kairaluoma MV. The role of mediolateral episiotomy during labour: analysis of risk factors for obstetric anal sphincter tears. Acta Obstet Gynecol Scand 2006; 85(7): 856-60.

15. De Leeuw JW, Struijk PC, Vierhout ME, Wallenburg HC. Risk factors for third degree perineal ruptures during delivery. BJOG 2001; 108: 383-7.

16. Handa VL, Danielsen BH, Gilbert WM. Obstetric anal sphincter lacerations. Obstet Gynecol 2001; 98: 225-30.
17. Petersen LK, Uldbjerg N. Cervical hydroxyprolin concentration in relation to age. In: Lippert PC, Woessner JF, eds. The extracellular matrix of the uterus, cervix and the fetal membranes. New York: Perinatol Press, 1991: 138 -9.

18. Sorensen M, Tetzschner T, Rasmussen 00 et al. Sphincter rupture in childbirth. Br J Surg 1993; 80: 392-4.

19. Crawford LA, Quint EH, Pearl ML, De Lancey JO. Incontinence following rupture of the anal sphincter during delivery. Obstet Gynecol, 1993; 82: 527-31.

20. Combs CA, Robertson PA, Laros RK Jr. Risk factors for thirddegree and fourth- degree perineal lacerations in forceps and vacuum deliveries. Am J Obstet Gynecol, 1990; 163: 100-4.

21. Bodner-Adler B, Bodner K, Kaider A et al. Risk factors for third- degree perineal tears in vaginal delivery, with an analysis of episiotomy types. J Reprod Med, 2001; 46: 752-6

22. Gupta N, Kiran TU, Mulik V et al. The incidence, risk factors and obstetric outcome in primigravid women sustaining anal sphincter tears. Acta Obstet Gynecol Scand, 2003; 82: 736-43.

23. De Parades V, Etienney I, Thabut D et al. Anal sphincter injury after forceps delivery: myth or reality? A prospective ultrasound study of 93 females. Dis Colon Rectum, 2004; 47: 24-34.

24. Carroli G, Mignini L. Episiotomy for vaginal birth. Cochrane Database Syst Rev 2009; 3: CD000081.

25. Raisanen SH, Vehvilainen-Julkunen K, Gissler M et al. Lateral episiotomy protects primiparous but not multiparous women from obstetric anal sphincter rupture. Acta Obstet Gynecol Scand, 2009; 88(12): 1365-72.

26. Angioli R, Gomez-Marin O, Cantuaria G et al. Severe perineal lacerations during vaginal delivery: the University of Miami experience. Am J Obstet Gynecol, 2000; 182: 1083-5.

27. Bodner K, Bodner-Adler B, Wagenbichler P et al. Perineal lacerations during spontaneous vaginal delivery. Wien Klin Wochenschr, 2001; 113: 743-6.

28. Bek KM, Laurberg S. Risks of anal incontinence from subsequent vaginal delivery after a complete obstetric anal sphincter tear. BJOG, 1992; 99: 950-4.

29. Shiono P, Klebanoff MA, Carey JC. Midline episiotomies: more harm than good? Obstet Gynecol, 1990; 75: 765-70.

30. Andrews V, Sultan AH, Thakar R et al. Risk factors for obstetric anal sphincter injury: a prospective study. Birth, 2006; 33: $117-22$. 